\title{
Jak w zaprojektowanym Wszechświecie zdefiniować to, co niezaprojektowane *
}

Argument z projektu, przeformułowany obecnie przez sympatyków ruchu Inteligentnego Projektu, jest oparty przede wszystkim na przeciwstawieniu rzeczy zaprojektowanych rzeczom niezaprojektowanym. Fakt ten jest jednak ktopotliwy dla chrześcijan. Skoro bowiem twierdza oni, że Bóg zaprojektowat cały Wszechświat, to jak można mówić, że coś nie jest zaprojektowane? W mojej opinii problem ten jest równoważny problemowi wolnej woli, czy też moralnego zła, a jako taki może znaleźć rozwiazanie na gruncie dawnych koncepcji filozoficznych, które dotyczyty tych kwestii - chodzi zwłaszcza o pojęcie różnych poziomów opisu oraz Augustyńska koncepcję różnych poziomów zdolności.

Dla wielu ludzi argument z projektu - kojarzony z Williamem Paleyem, ${ }^{1}$ mający jednak korzenie w starożytności ${ }^{2}-$ długo był intui-

\footnotetext{
* David W. Snoke, „Defining Undesign in a Designed Universe”, Perspectives on Science and Christian Faith, December 2008, vol. 60, no. 4, s. 225-232, http://www.asa3.org/ASA/ PSCF/2008/PSCF12-08Snoke.pdf (13.01.2010). Za zgodą Autora z języka angielskiego przełożył Dariusz Sagan. Recenzent: Kazimierz Jodkowski, Zakład Logiki i Metodologii Nauk Uniwersytetu Zielonogórskiego.

${ }^{1}$ William Paley, Natural Theology, ed. Matthew D. Eddy and David Knight, Oxford University Press, New York 2006.

${ }^{2}$ Por. np. William A. Dembski, „The Design Argument”, w: Gary B. Ferngren (ed.), The History of Science and Religion in the Western Tradition: An Encyclopedia, Garland,
} 
cyjnie przekonywający: jeżeli coś wygląda na zaprojektowane, to można zasadnie sądzić, że istotnie jest to rezultat projektu. Posłużmy się słynną analogią Paleya. Znajdując w lesie zegarek, doszlibyśmy do wniosku o istnieniu zegarmistrza nawet wtedy, gdybyśmy nie znali historii tego przyrządu. Rozważmy też podobny przykład. Jeśli wejdziemy do pokoju i zobaczymy stół, na którym leży sto sześciościennych kostek do gry, wszystkie obrócone ścianką z jednym oczkiem do góry, to będziemy „wiedzieć”, że ustawiła je tak jakaś osoba. Nie wiedzielibyśmy, jak lub kiedy tego dokonała - być może żmudnie układała je po kolei, a może ktoś inny wyprodukował kostki z obciążeniem na jedną ściankę i wystarczyło nimi rzucić. Tak czy owak, wzorzec ukazywany przez kostki ma cechy, które zdają się jednoznacznie podpowiadać naszej intuicji, że jego utworzenie wymagało udziału inteligencji i planowania.

Zwolennicy współczesnej teorii inteligentnego projektu (ID - Intelligent Design), tacy jak Dembski ${ }^{3}$ i Behe,${ }^{4}$ stosują w zasadzie ten sam argument, ale podjęli nadto próbę ścisłego określenia atrybutów, pozwalających wnioskować o projekcie. Wydaje się, jakby ludzie mieli wrodzone wyczucie rozpoznawania projektu, podobnie jak innych rzeczy, na przykład ciepła i zimna oraz głośnych i cichych dźwięków, a nawet czegoś tak subtelnego jak piękno i wina. Owe wrodzone sposoby wyczuwania umożliwiają, $\mathrm{z}$ jednej strony, łatwe rozpoznanie czegoś, kiedy to widzimy, ale dla innych mogą stanowić przeszkodę w zrozumieniu, co mamy na myśli - jedna osoba może powiedzieć: „to wygląda na zaprojektowane”, podczas gdy inna temu zaprzeczy. I tak samo ktoś może uznawać jakiś obraz za piękny, a komuś innemu może się on w ogóle nie podobać.

New York 2000, s. 75-77.

${ }^{3}$ William A. Dembski, No Free Lunch: Why Specified Complexity Cannot Be Purchased without Intelligence, Rowman and Littlefield, Lanham, Maryland 2006.

${ }^{4}$ Michael J. Behe, Czarna skrzynka Darwina. Biochemiczne wyzwanie dla ewolucjonizmu, przeł. Dariusz Sagan, Biblioteka Filozoficznych Aspektów Genezy, t. 4, Wydawnictwo MEGAS, Warszawa 2008. 
Współczesna nauka daje nam jednak nadzieję, że wiele $\mathrm{z}$ tego, co uważano wcześniej za subiektywne odczucia, da się zdefiniować w bardziej ścisły sposób. Na przykład sto lat temu ciepło i zimno były jedynie subiektywnie odczuwane: jedna osoba czuła, że w pokoju jest zimno, a inna, że jest ciepło. Dzięki wynalezieniu termometrów i sformułowaniu kinetycznej teorii gazów możemy dzisiaj znacznie precyzyjnej określać to, co było niegdyś zaledwie subiektywnym odczuciem. Podobnie potrafimy teraz mierzyć głośność dźwięków przy pomocy decybelomierza. Nadzieja, że ludzkie wyczucie rozpoznawania projektu nie musi pozostać na zawsze czymś subiektywnym lub niedefiniowalnym, jest zatem w pełni uzasadniona.

Zwiększenie ścisłości wymaga dokonania rozróżnień. Jak wskazują oba przytoczone wcześniej przykłady (zegarka w lesie i kostek do gry na stole), rozpoznajemy coś jako zaprojektowane dzięki porównaniu tego z czymś, co na takie nie wygląda. Zegarek uznajemy za zaprojektowany dlatego, że nie przypomina kamienia lub innego przedmiotu, na jaki spodziewamy się natknąć w lesie. Uważamy, że kostki ukazują wzorzec utworzony przez jakąś osobę, ponieważ nie przypisalibyśmy tego skutku losowemu rzutowi. Intuicyjnie rozpoznajemy zaprojektowane przedmioty po części poprzez porównanie ich z przedmiotami, które nie powstały na skutek projektu. Zwolennicy ID stosują podobną argumentację. Do wniosku, że pewne zjawiska przyrodnicze, na przykład mechanizmy żywych komórek, są zaprojektowane, prowadzi porównanie ich ze skutkami procesów losowych.

Dla chrześcijan zasadniczym problemem jest jednak to, że uznajemy Boga za projektanta całego Wszechświata. Czy mówiąc, że niektóre rzeczy wyglądają na zaprojektowane, zaś inne na takie nie wyglądają, odrzucamy pogląd, że chwałę Boga można dostrzec we wszystkim, co istnieje? Ten problem jest zapewne główną przyczyną niechęci wielu chrześcijan do ruchu ID, można bowiem zapytać, czy zwolennicy ID widzą rękę Boga wyłącznie w niezwykłych lub cudownych zjawiskach, ale nie w normalnym funkcjonowaniu Wszechświata? 
Mamy tu do czynienia $\mathrm{z}$ dylematem. $\mathrm{Z}$ jednej strony, jeśli powiemy, że wszystko wygląda na zaprojektowane, to argument z projektu straci moc. To w zasadzie tak, jakbyśmy powiedzieli, że pod pewnym względem wszystkie rzeczy są do siebie podobne i nie możemy określić, jak te rzeczy by wyglądały, gdyby nie były zaprojektowane. $Z$ drugiej zaś strony, jeżeli przyjmiemy, że tylko niektóre rzeczy są zaprojektowane, to niejako oskarżymy Boga o to, że czegoś nie zrobił dobrze.

\section{Indukcyjne wnioskowanie o projekcie}

Aby lepiej wyjaśnić, na czym polega ten problem, sformułuję argument z projektu nieco ściślej. Argument ten ma w zasadzie charakter indukcyjny i można go streścić następująco:

1. Z doświadczenia wiemy, że pewne rzeczy zostały zaprojektowane przez istoty inteligentne, to jest przez ludzi lub zwierzęta, posiadające pewien stopień inteligencji.

2. Na podstawie doświadczenia dowiadujemy się też, że pewne inne rzeczy nie są wynikiem projektu istot inteligentnych.

3. Doświadczenie podpowiada nam ponadto, że każda inteligentnie zaprojektowana rzecz ma określone cechy, których nie posiada nic, o czym wiemy, że nie jest zaprojektowane.

4. Kiedy zatem mamy do czynienia ze zjawiskami o nieznanej historii i mają one cechy rzeczy zaprojektowanych, wnioskujemy indukcyjnie, że zaprojektowały je istoty inteligentne.

$\mathrm{W}$ tej postaci jest to $\mathrm{w}$ pełni prawomocny argument indukcyjny, nieustannie stosowany w codziennym życiu i w nauce. Oto przykład zastosowania tego typu argumentacji przez naukowców: skoro obser- 
wujemy, że wszystkie atomy wodoru pochłaniają światło o konkretnej długości fali i żadne inne atomy czy cząstki takiego światła nie pochłaniają, to jeżeli coś (na przykład międzygwiazdowy obłok gazu) je pochłania, możemy uznać, że w skład tego czegoś wchodzi wodór. Tego typu rozumowaniem - którego podstawą są „charakterystyczne” oznaki istnienia danej rzeczy, rozpatrywane w ścisłym związku z czymś innym - posługujemy się praktycznie nieustannie.

Argumentacji tej często stawiane są dwa zarzuty. Pierwszy stwierdza, że w kroku 4. pojęcie ,istoty inteligentnej” nie jest dobrze zdefiniowane. Czy skoro jedynymi istotami inteligentnymi, z którymi mamy regularnie do czynienia, są organizmy z krwi i kości, to inteligentny projektant też musi być z krwi i kości? Jeśli owa istota nie jest dokładnie taka, jak my, to skąd mamy wiedzieć, jaka jest? Czy może być to Wielki Potwór Spaghetti? Czy wolno nam utożsamiać owego projektanta $\mathrm{z}$ biblijnym Bogiem?

Argument ten nie może, oczywiście, doprowadzić bezpośrednio do biblijnego Boga. Fakt istnienia projektu świadczy tylko o jednym atrybucie projektanta, mianowicie o jego zdolności tworzenia sił teleologicznych. Znaczy to, że projektant musi posiadać przynajmniej zdolność obierania celu (wyobrażania sobie innego stanu rzeczy, niż jest obecnie) i działania jako czynnik przyczynowy, który ten cel realizuje. Tę zdolność może mieć każda istota inteligentna, wliczając $\mathrm{w}$ to biblijnego Boga, Zeusa, Thora czy nawet Wielkiego Potwora Spaghetti. Rozstrzygnąć pomiędzy tymi możliwymi projektantami możemy tylko za sprawą dodatkowych argumentów i świadectw, takich jak objawienie się nam którejś $\mathrm{z}$ tego typu istot $\mathrm{i}$ komunikacja $\mathrm{z}$ nią.

Ze względu na minimalistyczny charakter argumentu $\mathrm{z}$ projektu niektórzy oskarżyli zwolenników ID o nieszczerość: wszyscy wiemy, że „naprawdę" wierzą oni w biblijnego Boga (w istocie nie jest to prawda: mocne argumenty $\mathrm{z}$ inteligentnego projektu wysunęli na przy- 
kład Anthony Flew, ${ }^{5}$ Paul Davies, ${ }^{6}$ Michael Denton ${ }^{7}$ i Frank Tipler, ${ }^{8}$ którzy są różnego rodzaju deistami; argumentację ID akceptują również Gerald Schroeder, ${ }^{9}$ który jest Żydem, oraz muzułmanin Mustafa Akyol ${ }^{10}$ ). Takie oskarżenia zdradzają brak zrozumienia natury argumentacji, opartej na świadectwach empirycznych. Często świadectwa mogą zawężać zakres możliwości, nie wskazując wyłącznie na jedną opcję. Na przykład jeżeli na miejscu zbrodni znaleziono czarny włos, oskarżyciel może udowodnić, że zabójca ma czarne włosy, ale nie jest w stanie wskazać w ten sposób jakiejś konkretnej osoby, a co najwyżej zawęża zbiór możliwości. Wskazanie konkretnego podejrzanego wymaga dodatkowych informacji, a czasem nawet tożsamość sprawcy pozostaje wyłącznie w sferze domysłów.

Drugi zarzut (to właśnie on jest przedmiotem zainteresowania niniejszego artykułu) ma większą siłę: jak - w kroku 2. - możemy ustalić, że mamy do czynienia ze zbiorem rzeczy, które - zgodnie z naszą wiedzą - nie zostały zaprojektowane? Chrześcijanie twierdzą przecież, że cały Wszechświat został zaprojektowany przez Boga.

\footnotetext{
${ }^{5}$ Antony Flew and Gary Habermas, „My Pilgrimage from Atheism to Theism”, Philosophia Christi, Winter 2005 (thum. pol.: „Antony Flew: Moja pielgrzymka od ateizmu do teizmu", przeł. Krzysztof Jasiński, Fronda.pl, 19 maja 2010, http://fronda.pl/news/czytaj/antho ny_flew_moja_pielgrzymka_od_ateizmu_do_teizmu [24.05.2010]); Antony FLEw, Bóg istnieje. Dlaczego najsłynniejszy ateista zmienil swój światopogląd?, przeł. Robert Pucek, Fronda, Warszawa 2010.

${ }^{6}$ Paul Davies, Plan Stwórcy. Naukowe podstawy racjonalnej wizji świata, przeł. Marek Krośniak, Wydawnictwo Znak, Kraków 1996.

${ }^{7}$ Michael Denton, Evolution: A Theory in Crisis, Adler and Adler, Chevy Chase, Maryland 1986.

${ }^{8}$ John D. Barrow and Frank Tipler, The Anthropic Cosmological Principle, Oxford University Press, New York 1987.

${ }^{9}$ Gerald L. Schroeder, The Science of God, Broadway Books, New York 1997.

${ }^{10}$ Por. np. „In the Beginning”, The Economist, 19 April 2007.
} 


\section{Poziomy opisu}

Próbując rozwiązać ten dylemat, możemy rozpocząć od rozważenia koncepcji różnych poziomów opisu. Liczni autorzy, między innymi Douglas Hofstadter ${ }^{11}$ i Donald MacKay, ${ }^{12}$ zasugerowali, że aby rozwiązać problem, czy istnienie wolnej woli i świadomości da się pogodzić z determinizmem, należy uwzględnić różne poziomy opisu. Rozróżnienie poziomów opisu pomaga też wytłumaczyć istnienie rzeczy niezaprojektowanych w świecie zaprojektowanym przez Boga. W mojej opinii problem zdefiniowania tego, co niezaprojektowane, w zaprojektowanym Wszechświecie przekłada się bezpośrednio na problem zdefiniowania wolnej woli we Wszechświecie kontrolowanym przez Boga; oba te problemy mają ponadto związek z przekonaniem, że Bóg czegoś nie zrobił. Niektórzy czytelnicy z pewnością uznają to za niewielką pomoc - aby sformułować argument z projektu, w pierwszej kolejności należałoby bowiem rozwiązać jeden z największych odwiecznych problemów filozoficznych. Dostrzeżenie tego związku może jednak okazać się pomocne, otwiera bowiem możliwość posłużenia się poglądami dawnych wielkich myślicieli, którzy podjęli próbę rozwiązania tych kwestii.

Do każdego z wyżej wymienionych problemów możemy odnieść pojęcie „dziedziny kontroli”, w ramach której można powiedzieć, że tylko istoty żywe są istotnymi czynnikami teleologicznymi. W odniesieniu do problemu wolnej woli chrześcijanie twierdzą, z jednej strony, że Bóg jest pierwotną przyczyną wszechrzeczy, ale uważają ponadto, że ludzie kontrolują i są odpowiedzialni za pewne rzeczy w takim stopniu, że możemy uznać, iż nie odpowiada za nie Bóg. W istocie nie należy utrzymywać, że Bóg odpowiada za wszystko, jest to bo-

\footnotetext{
${ }^{11}$ Douglas Hofstadter, Gödel, Escher, Bach: An Eternal Golden Braid, Basic Books, New York 1979.

${ }^{12}$ Donald M. MacKay, Brains, Machines, and Persons, Eerdmans, Grand Rapids, Michigan 1980.
} 
wiem stanowisko panteistyczne. Uznanie, iż Bóg robi wszystko, jest równoznaczne z przyjęciem poglądu, że gdy widzimy, iż jakaś istota coś robi, musimy przypisać to działanie samemu Bogu. Tymczasem teologia chrześcijańska podkreśla, że Bóg jest odrębny od stworzenia i chociaż można powiedzieć, iż to Bóg jest ostateczną przyczyną jakiegoś działania, nie zawsze należy sądzić, że to On je wykonał. Kiedy przewraca się drzewo, mówimy prawidłowo, że to drzewo się przewróciło, nie zaś Bóg. Kiedy bóbr buduje tamę, nie mówimy, że to Bóg ją zbudował - zrobił to bóbr. Podobnie, kiedy ktoś grzeszy, nie mówimy, że to Bóg zgrzeszył. ${ }^{13}$

W kwestii problemu zdefiniowania tego, co niezaprojektowane, chrześcijanie utrzymują, że wprawdzie Bóg jest projektantem Wszechświata i jego pierwotną przyczyną, ale stworzył w świecie ludzi także pewne rzeczy, nad którymi to my sprawujemy kontrolę i za które odpowiadamy. Podobnie jak możemy dokonywać niegodziwych uczynków, nie oskarżając Boga o niegodziwość, tak możemy czegoś nie zrobić lub nie zaprojektować, nie zarzucając Bogu lenistwa. W obrębie naszej sfery kontroli, sfery świadomości, możemy swobodnie czynić dobro albo zło, jak również projektować coś albo nie podejmować takiego działania.

W klasycznej teologii rozróżnienie sfer czy poziomów kontroli sprowadza się do rozróżnienia pomiędzy przyczynami „pierwotnymi” a przyczynami „wtórnymi”. Przyczyny pierwotne to działania przypisywane bezpośrednio Bogu, takie jak pierwszy akt stworzenia i późniejsze cudowne interwencje. Przyczyny wtórne to natomiast działania przypisywane czynnikom istniejącym w tym świecie, które, oczywi-

\footnotetext{
${ }^{13}$ Niektóre fragmenty Biblii zdają się zamazywać to rozróżnienie, np. Amos 3:6 - „Czyż zdarza się w mieście nieszczęście, by Pan tego nie sprawił?” (lub „stworzył”). Biblia często mówi o boskiej przyczynowości niższego rzędu, jednak wyraźnie wskazuje również, że nie wolno przypisywać Bogu bezpośredniego działania w każdym możliwym przypadku, np. w Jer. 7:31 - „I zbudowali wyżynę [...] aby palić w ogniu swoich synów i córki, czego nie nakazałem i co nie przyszło Mi nawet na myśl”, oraz w liście św. Jakuba 1:13-14 - „Kto do znaje pokusy, niech nie mówi: «Bóg mnie kusi» [...] To własna pożądliwość wystawia każdego na pokusę i nęci”. Już sama koncepcja kary implikuje, że na pewnym poziomie istnieje rozróżnienie pomiędzy czynami Stwórcy a działaniami stworzeń.
} 
ście, ostatecznie zawdzięczają swe istnienie boskim przyczynom pierwotnym, ale same również pełnią funkcję czynników przyczynowych. Jest to inny sposób wyrażenia koncepcji różnych poziomów opisu. Bóg jest pierwotną przyczyną „niższego" poziomu, czyli praw fizyki i wszystkiego, co doprowadziło do zaistnienia ludzi. Jednocześnie sami jesteśmy czynnikami przyczynowymi na „wyższym” poziomie naszego własnego doświadczenia. Mimo iż nie jestem stwórcą Wszechświata, ani go nie kontroluję, działam w sferze, nad którą sprawuję kontrolę. Mogę pościelić łóżko lub zaprojektować domek dla ptaków, ale nie muszę tego robić.

Każdy chrześcijanin przyjmuje to rozróżnienie. $Z$ jednej strony zgadzamy się, że ludzie mogą grzeszyć i płacić za swoje grzechy, z drugiej zaś dziękujemy Bogu za decyzje innych ludzi, które stanowią odpowiedź na nasze modlitwy. Nie twierdzimy, że Bóg w odpowiedzi na modlitwy pominął wolę tych ludzi, ani że w istocie decyzji tych nie podjęli bezpośrednio oni, lecz właśnie Bóg. Uznajemy natomiast, że Bóg tak zaaranżował przebieg historii „niższego poziomu”, aby doprowadził do zamierzonego skutku. Nie modlę się słowami: „Dziękuję Ci, Boże, za propozycję zatrudnienia”, lecz: „Dziękuję Ci, Boże, że tak pokierowałeś pracodawcą, aby złożył mi ofertę pracy”.

Choć dokonywanie takich rozróżnień przychodzi ludziom zupełnie naturalnie, większy problem sprawia nam spójne wyrażanie związku pomiędzy poziomem niższym a poziomem wyższym. Nad możliwością pogodzenia obu tych poziomów opisu debatowali i debatują przedstawiciele dwóch chrześcijańskich szkół myślenia. ${ }^{14}$ Teologowie „arminiańscy” twierdzą, że Bóg jest pierwotną przyczyną wszechrzeczy, w tym istnienia ludzi i innych czynników przyczynowych we Wszechświecie, ale powiedzieliby również, że ludziom nadano unikatową zdolność do naśladowania mocy Boga jako pierwotnej przyczy-

\footnotetext{
${ }^{14}$ Arminiusz i Kalwin byli protestantami i od ich imion nazwano odpowiednie ruchy protestanckie, ale podobne stanowiska na ten temat przyjmowano w całej historii kościoła, nie tylko $\mathrm{w}$ ramach protestantyzmu.
} 
ny. Zgodnie z tym poglądem, od kiedy Bóg stworzył ludzi, niektóre ludzkie wybory znajdują się poza Jego kontrolą.

Teologowie „kalwińscy” powiedzieliby zaś, że nic, wliczając w to wszystkie ludzkie decyzje, nie wymyka się kontroli Boga, ale fakt ten nie odbiera ludziom wolności. Zgodnie z rozumowaniem kalwinistów boska moc przyczynowa działa na niższym poziomie, wywołując pragnienia, które skłaniają ludzi do działania. Jak argumentował Jonathan Edwards, ${ }^{15}$ zdanie ,zawsze robisz to, co chcesz” wskazuje zarówno na wolność, jak na przeznaczenie. Biorąc pod uwagę własne pragnienia, podejmujemy teleologiczne decyzje o tym, co możemy zrobić, aby je spełnić, ale to, czego chcemy, poprzedza nasze decyzje i pełni nad nimi kontrolę. Na wyższym poziomie punktem wyjściowym są konkretne pragnienia, które stają się następnie bodźcem ludzkiego działania. Natomiast na niższym poziomie Bóg stwarza wszystkie różnorodne przyczyny, które wywołują nasze pragnienia, a następuje to w długim, przyczynowo-skutkowym łańcuchu fizycznych oddziaływań i odczuć, składających się na to, jacy jesteśmy.

Rzecz jasna, w niniejszym artykule nie rozstrzygnę debaty pomiędzy arminianami a kalwinami. Postaram się za to wykazać, że bez względu na to, za którą szkołą myślenia się opowiemy, rozróżnienie różnych poziomów opisu jest naturalne i pomaga zrozumieć, co mamy na myśli mówiąc, że pewne rzeczy nie są zaprojektowane. Rozważmy przykład nastolatka, kontrolującego układ rzeczy w swoim pokoju. Nastolatek niektóre rzeczy zaprojektował, jak zestaw płyt CD, ułożonych w porządku alfabetycznym, a inne pozostawił przypadkowi, jak ubrania, porozrzucane na podłodze. Możemy oczywiście uznać, że rozmieszczenie tych ubrań $\mathrm{w}$ istocie nie jest losowe, że w momencie rozrzucania podlegały one zaprojektowanym prawom fizyki, a nawet, że konkretny sposób ich rozrzucenia nie był losowy, lecz uprzednio ustanowiony przez Boga, który taką metodą chciał zrealizować swoje nieprzeniknione cele. Jednak na poziomie sfery odpowiedzialności

\footnotetext{
${ }^{15}$ Jonathan Edwards, Freedom of the Will, Yale University Press, New Haven, Connecticut 1957.
} 
i kontroli nastolatka takie rozważania są nieistotne. Bóg mógł ustanowić i zaprojektować wszystko, ale nastolatek nie potrafi tego, a w związku z tym rzeczy znajdujące się w jego pokoju można zaliczyć do dwóch kategorii: rzeczy, które są, i rzeczy, które nie są celowo uporządkowane. Pozostaje tylko pytanie: czy istnieją jakieś obserwowalne cechy, które odpowiadają wyłącznie rzeczom należącym do pierwszej kategorii, ale nie posiadają ich przedmioty należące do tej drugiej kategorii? Zauważmy przy tym, że istnienia takich cech nie sposób wykluczyć a priori.

Odrzucenie poglądu, w myśl którego jesteśmy w stanie ustalić, że pewne rzeczy nie zostały zaprojektowane, jest w istocie równoznaczne $\mathrm{z}$ całkowitym odrzuceniem idei losowości. Upieranie się, że wszystko zostało stworzone przez dobrego Boga i dlatego nie można mówić, iż coś nie jest zaprojektowane, zmusza do przyjęcia, że na żadnym poziomie nie ma zdarzeń losowych, niezaplanowanych, które można porównać ze zdarzeniami zaplanowanymi. Pojęcie losowości stanowi jednak podstawę tak dobrze ugruntowanej dyscypliny naukowej jak mechanika statystyczna. Zakładając nawet, że wszystkie atomy gazu podlegają deterministycznym prawom, możemy stwierdzić, że - zgodnie z naszą najlepszą wiedzą - atomy zachowują się w sposób losowy. Występująca w termodynamice idea ,gruboziarnistości” ${ }^{16}$ (coarse graining) to kolejny przykład istnienia różnych poziomów opisu. $\mathrm{Na}$ poziomie mikroskopowym atomy działają deterministycznie, lecz na poziomie makroskopowym ich zachowanie można uznać za losowe.

Przyjęcie, że zachowanie wielu rzeczy na poziomie makroskopowym jest losowe, doprowadziło do sformułowania powszechnie uznawanych praw matematycznych, z których wynikają niekiedy zaskakujące konsekwencje, na przykład, że pewne wzorce tworzą się sponta-

\footnotetext{
${ }^{16}$ Omówienie idei gruboziarnistości można znaleźć w: George E. Uhlenbeck, „Problems of Statistical Physics", w: Jagdish Menra (ed.), The Physicist's Conception of Nature, D. Reidel, Dordrecht, Holland 1973, s. 501. W komentarzu na końcu tego artykułu Peierls twierdzi, że idea gruboziarnistości pozwala wykluczać „zwariowane” mikroskopowe stany początkowe.
} 
nicznie. Zgodnie z Prigoginem ${ }^{17}$ i wieloma innymi badaczami dzięki takim statystycznym prawom można zrozumieć każde zjawisko makroskopowe. Teoria inteligentnego projektu głosi natomiast, że tylko niektóre zjawiska da się wytłumaczyć prawami statystycznymi, zaś inne najlepiej wyjaśnić zdarzeniami nielosowymi, takimi mianowicie, które Bóg spowodował albo bezpośrednio, czyli w sposób cudowny, albo „zmanipulował” je poprzez dobór specyficznych warunków początkowych.

Indukcyjny argument ID można więc przeformułować następująco:

1. W ramach naszej „dziedziny kontroli” obserwujemy trzy rodzaje rzeczy: (1) te, których pochodzenie znamy, a które zostały zaprojektowane przez inteligentną osobę lub zwierzę; (2) te, których pochodzenie znamy, a które są wytworem wyłącznie sił losowych i niekierowanych, to jest nie zostały zaprojektowane; oraz (3) te, których pochodzenie nie jest nam znane.

Zauważmy, że nasza wiedza o pochodzeniu danej rzeczy nie obejmuje ostatecznego pochodzenia wszystkich jej części, a jedynie pochodzenie w obrębie naszej dziedziny kontroli. W koncepcji tej zakłada się, że ludzie (i niektóre zwierzęta) dysponują mocą stwórczą - że niektóre rzeczy rzeczywiście zostały stworzone od początku do końca przez nas. Mogę na przykład stworzyć domek dla ptaków. Nie stworzyłem wszystkich jego części - drewna, gwoździ, kleju - ale przedmiot, jakim jest ów domek, wcześniej nie istniał, zaś teraz już istnieje. Na podłodze w warsztacie pojawiły się również kolejne nowe przedmioty, jak kupki trocin czy inne pozostałości po procesie budowy domku, które także stworzyłem, jednak bez planu lub zamysłu. Nie zaprojektowałem ich układu - z perspektywy mojego makroskopowego poziomu opisu utworzyły się one losowo. Są to zatem nowostwo1980.

${ }^{17}$ Ilya Prigogine, From Being to Becoming, W.H. Freeman, San Francisco, California 
rzone przedmioty, których pochodzenie znam i które należą do mojej dziedziny kontroli.

Istoty żywe zaliczają się natomiast do kategorii (3). Mimo iż możemy zaobserwować narodziny nowej istoty żywej, należy to interpretować po prostu jako nową egzemplifikację istniejącego już systemu, nie zaś jako nowe stworzenie - nie daje to nam bezpośredniej wiedzy o pochodzeniu życia.

2. W podzbiorze rzeczy z kategorii (1) i (2), których pochodzenie znamy w obrębie naszej dziedziny kontroli, możemy wydzielić zbiór cech A, przynależący wszystkim rzeczom, o których wiemy, że zostały przez kogoś zaprojektowane, ale nie przynależący rzeczom, które - zgodnie z naszą wiedzą - powstały losowo.

3. Rozumując indukcyjnie dochodzimy do wniosku, że zbiór cech A jest charakterystyczny dla rzeczy zaprojektowanych. Podobnie postępujemy w odniesieniu do rzeczy z kategorii (3), czyli takich, których pochodzenia nie znamy.

Możemy ponadto rozszerzyć zastosowanie tej procedury na rzeczy, którym odpowiadają inne poziomy opisu. A więc schodząc na przykład na poziom mikroskopowy, mogę chcieć rozstrzygnąć, czy wartości stałych fizycznych (ładunek elektronu, prędkość światła) da się opisać jako rezultat wyłącznie zdarzeń losowych na jeszcze niższym poziomie (pól kwantowych), czy też mają one cechy wydzielone w zbiorze A, które łączą je z rzeczami zaprojektowanymi w dziedzinie naszego doświadczenia. 


\section{Hierarchia poziomów}

Ostatnia uwaga uzmysławia możliwość istnienia hierarchii projektu. Do tej pory skupiałem się na dwóch poziomach opisu - moim własnym, na którym mam dziedzinę kontroli, oraz niższym, mikroskopowym poziomie rzeczy, które zwykle uważam za losowe. Można jednak pójść dalej i dopuścić wiele poziomów - na każdym z nich niektóre rzeczy mogą wyglądać na losowe, a inne - na zaprojektowane. Można więc mówić o hierarchii poziomów przyczyn (na przykład o poziomach: subatomowym, atomowym, komórkowym, organicznym, ludzkim, wspólnotowym, społecznym), nie zaś tylko o dwóch kategoriach stosowanych w klasycznej teologii - przyczynach pierwotnych i wtórnych. To podejście w zasadzie rozbija kategorię przyczyn wtórnych (rzeczy niespowodowanych bezpośrednio przez Boga) na kilka podkategorii.

Augustyn z Hippony wyobrażał sobie podobną hierarchię poziomów stworzenia ${ }^{18}$ i uważał, że na każdym poziomie Bóg nadał stworzeniu określone zdolności - większe na wyższych poziomach - lecz na żadnym z nich stworzeniu nie przysługują wszystkie dobre atrybuty samego Boga. Idea poziomów zdolności dostrzegalna jest również w słowach Jezusa: ,jesteście ważniejsi niż wiele wróbli” (Łuk. 12:7), który powiedział jednocześnie, że Bóg troszczy się o każdego, bez wyjątku, wróbla. Tę koncepcję poziomów zdolności da się przeformułować tak, aby można było mówić o poziomach projektu. Na najniższym poziomie wszystko jest rezultatem projektu w sensie podporządkowania zaprojektowanym prawom przyrody, zaś na wyższym poziomie niektóre rzeczy ukazują jeszcze wyższe stopnie projektu, czyli charakteryzują się wzorcami, których nie da się wywieść wyłącznie z niższych stopni projektu. Można zatem argumentować, że życie stanowi nowy zaprojektowany wzorzec, wzbogacający projekt na niż-

\footnotetext{
${ }^{18}$ Św. Augustyn, Wyznania, przeł. Zygmunt Kubiak, Wydawnictwo Znak, Kraków 2001. Zagadnieniu temu poświęca Augustyn kilka rozdziałów, bowiem problem zła był niezmiernie ważny w procesie jego nawrócenia się na wiarę chrześcijańską.
} 
szym, mikroskopowym poziomie, natomiast świadomość to kolejny poziom projektu, wzbogacający życie. Nie twierdzimy tym samym, że rzeczy ukazujące projekt jedynie na niższych poziomach są nieudanymi tworami Boga. Chodzi wyłącznie o to, że nie ukazują one projektu $\mathrm{w}$ takim stopniu jak inne rzeczy, widziane $\mathrm{z}$ wyższego poziomu.

W ten sposób Augustyn mierzył się z problemem zła. Wskazywał on, że stworzeniu na każdym poziomie przysługuje pewien stopień dobra, a zatem można sensownie twierdzić, że całe stworzenie jest dobre, ale nie na każdym poziomie obdarzone jest ono najwyższym stopniem dobra. Nawet ludzie pozbawieni skrupułów zostali obdarzeni pewnym stopniem dobra (w tym sensie, że mogą dokonywać wyborów moralnych), lecz nie otrzymali większego daru, jakim jest zdolność odczuwania żalu. Augustyn nie powiedziałby, że ci ludzie są nieudanymi stworzeniami, a jedynie, że nie otrzymali od Boga największych zdolności. Podobnie zwolennik ID twierdzący, że wynikiem projektu nie jest ani układ ubrań w zabałaganionym pokoju nastolatka, ani kupki trocin na podłodze w warsztacie, nie ma przez to na myśli, że ta część stworzenia nie gloryfikuje Boga, lecz że tym rzeczom brakuje większych zdolności - cech zaprojektowania na wyższym poziomie.

Mówi się o jeszcze wyższych poziomach opisu - społeczeństw i narodów. W Biblii Bóg często przemawia bezpośrednio do narodów jako bytów mających własny charakter, aczkolwiek z punktu widzenia narodu działania indywidualnych ludzi można traktować jako losowe.

Można także mówić o różnych stopniach zaprojektowania w obrębie tego samego poziomu hierarchii projektu. Niektóre argumenty przeciwko ID stwierdzają, że nieoptymalność projektu świadczy, iż jego źródłem nie jest Bóg. Za takie nieudolne projekty uważa się na przykład kciuk pandy czy odwróconą siatkówkę ludzkiego oka. Tymczasem w ujęciu Augustyna żadnej stworzonej rzeczy nie obdarzono każdą dobrą zdolnością, a część otrzymała więcej zdolności od innych. Istnienie czegoś o mniejszym stopniu projektu nie oznacza, że nic nie jest zaprojektowane. Na przykład odkrycie krótkiej przyśpiewki, napisanej przez Mozarta, nie dawałoby podstaw do wniosku, że był on 
kiepskim kompozytorem. Istnienie Mercedesa-Benza z kołpakami, które nie są tak aerodynamiczne, jak byśmy sobie życzyli, nie oznaczałoby, że samochód powstał na skutek działania procesów losowych. Ludzie tworzą wiele rzeczy o różnym zastosowaniu i nie ma żadnego powodu, dla którego Bóg nie mógłby postąpić tak samo. W ten sposób pojawia się możliwość ilościowego określenia stopni projektu, wykrywanego w danym układzie. Na przykład ubraniom wystającym $\mathrm{z}$ szuflady $\mathrm{w}$ pokoju nastolatka można przypisać większy stopień projektu niż ubraniom losowo porozrzucanym na podłodze, natomiast starannie złożone ubrania charakteryzowałyby się jeszcze wyższym stopniem zaprojektowania.

\section{Brakująca wielka metanarracja}

Teorię inteligentnego projektu krytykowano za to, że nie oferuje „wielkiej metanarracji”, to jest opowieści o tym, jak wszystko powstało. Teoretycy projektu formułują głównie twierdzenia jednostkowe: „To wygląda na zaprojektowane” oraz „To wygląda na niezaprojektowane" (na odpowiednim poziomie opisu). Niektórzy są tym poirytowani, ${ }^{19}$ gdyż zwolennicy ID na ogół nie mówią, skąd się ów projekt wziął.

Źródłem tej irytacji jest konflikt paradygmatów dotyczących natury samego wyjaśniania. W standardowo pojmowanej nauce wyjaśnienie ma postać historii, to znaczy scenariusza, przedstawiającego przyczynowo-skutkowy bieg zdarzeń, prowadzący do obecnego stanu rzeczy. Rewolucyjność ID polega na propozycji, że najlepsze dostępne wyjaśnienie danego stanu rzeczy w ogóle nie musi mieć charakteru historii.

\footnotetext{
${ }^{19}$ Por. np. Robert T. Pennock, „DNA by Design?: Stephen Meyer and the Return of the God Hypothesis", w: William A. Dembski and Michael Ruse (eds.), Debating Design: From Darwin to DNA, Cambridge University Press, New York 2004, s. 130.
} 
Można to zilustrować na przykładzie stu kostek do gry, który przytoczyłem już wcześniej. Jeśli wejdę do pokoju i zobaczę, że sto sześciościennych kostek do gry jest obróconych ścianką $\mathrm{z}$ jednym oczkiem do góry, to będę wiedział, że musiała mieć w tym udział jakaś osoba. Mogę wyobrazić sobie wiele możliwych scenariuszy zaistnienia tego samego stanu rzeczy: ktoś żmudnie układał kostki po kolei; ktoś wyprodukował je z obciążeniem na jedną ściankę; ktoś wyjął je z kupionego w sklepie opakowania, w którym były już tak ułożone i tak dalej. Zwolennik ID uznałby za dziwne, gdyby wniosek o działaniu jakiejś osoby odrzucono tylko dlatego, że nie posiadamy dodatkowej wiedzy, która pozwoliłaby rozstrzygnąć pomiędzy takimi różnymi scenariuszami. We wszystkich przypadkach liczy się fakt, że ktoś dopilnował, by kostki zostały ułożone, nie zaś rzucone w sposób losowy. Nawet jeśli chciałbym wiedzieć więcej, muszę zadowolić się dostępnymi informacjami. Na podstawie zaobserwowanego zjawiska moge odrzucić scenariusz, mówiący o losowym rzucie kostkami, lecz nie muszę wykazać prawdziwości żadnego z alternatywnych scenariuszy.

Jak już wspomniałem, zgodnie z koncepcją zjawisk emergentnych, zaproponowaną przez Prigogine'a i innych badaczy, wszystkie zjawiska makroskopowe można wyjaśnić w kategoriach praw statystycznych, czyli każdemu działaniu w świecie mikroskopowym przypisać charakter losowy. Zwolennicy ID wskazują natomiast, że pewnych rzeczy nie da się w ten sposób wyjaśnić - niektóre świadczą o projekcie, który nie mógł być rezultatem zdarzeń losowych. Jak dokładnie Bóg zrealizował projekt? Różni zwolennicy ID zaproponowali rozmaite scenariusze. Według jednego z nich w historii Wszechświata Bóg wielokrotnie posłużył się przyczynami pierwotnymi, czyli cudami. W innym już na samym początku stworzenia początkowy stan Wszechświata został tak ,zestrojony” na poziomie mikroskopowym za pomocą warunków początkowych, by w końcu powstał obserwowany przez nas projekt.

Czy ten ostatni pogląd różni się jakoś od emergentystycznego ujęcia Prigogine'a? Zarówno w tej teorii, jak i w koncepcji zestrojenia poziomu mikroskopowego projekt wyższego poziomu powstaje na 
skutek deterministycznych działań na poziomie niższym. Różnica polega na tym, że w ramach tego drugiego poglądu elementy prowadzące do pojawienia się projektu na wyższym poziomie nie są losowe. Jak wytłumaczył Michael Behe, aby uzyskać końcowy efekt, bilardzista może posłużyć się łańcuchem precyzyjnie dobranych przyczyn i skutków. ${ }^{20}$ Triki bilardowe robią na nas wrażenie właśnie dlatego, że nie potrafimy sobie wyobrazić, by przyczyną tego typu zjawisk były zdarzenia z niższego poziomu, które uznajemy za losowe.

Innymi słowy, w koncepcji zestrojenia poziomu mikroskopowego zdarzenia $\mathrm{z}$ niższych poziomów podpadają pod dwie kategorie: zdarzeń autentycznie losowych (z naszego punktu widzenia) oraz zdarzeń nielosowych, w przypadku których początkowy stan łańcucha przyczynowego został starannie dobrany przez istotę inteligentną. Zgodnie z poglądem Prigogine'a wszystkie zjawiska makroskopowe, w tym życie, można wyjaśnić w kategoriach jednej klasy zjawisk z niższego poziomu, mianowicie $w$ kategoriach zdarzeń losowych. ID odrzuca to przekonanie i stawia hipotezę o istnieniu innej klasy przyczyn poza zdarzeniami losowymi. To, czy ta nowa klasa obejmuje przyczyny pierwotne, to jest cuda (jak sugeruje pogląd ID, że zaszło wiele cudów), czy też przyczyny wtórne w postaci szczególnych warunków początkowych (postulowane w ramach poglądu ID, że poziom mikroskopowy został zestrojony), czy też jakieś połączenie tych dwóch rodzajów przyczyn, jest sprawą drugorzędną.

Trudno zatem oczekiwać od zwolenników ID, by zaoferowali wielką metanarrację na temat historii Wszechświata, nie o to bowiem im chodzi. W koncepcji ID obserwacja: „To wygląda na zaprojektowane", jest w pełni dopuszczalna jako twierdzenie jednostkowe oparte na postrzeganiu rzeczy, należących do dziedziny ludzkiego doświadczenia. Obserwacja ta może być zgodna z różnymi wielkimi metanarracjami, takimi jak kreacjonizm młodej Ziemi, interwencjonizm starej Ziemi, teistyczny ewolucjonizm, platoński deizm czy nawet koncepcja

\footnotetext{
${ }^{20}$ Michael J. Bene, The Edge of Evolution: The Search for the Limits of Darwinism, Free Press, New York 2007.
} 
stworzenia przez Wielkiego Potwora Spaghetti, ale nie jest od nich zależna.

ID wnosi do nauki zasadę ograniczającą, w myśl której zdarzenia losowe $\mathrm{z}$ niższego poziomu mają względnie niewielkie możliwości stwórcze. W tym sensie jest to zasada negatywna, a nie pozytywna, ale negatywne zasady są $\mathrm{w}$ nauce zjawiskiem powszechnym: zasada nieoznaczoności w mechanice kwantowej nakłada ograniczenie na to, co możemy dowiedzieć się o danej cząstce; drugie prawo termodynamiki głosi, że entropia nie może spontanicznie maleć; teoria względności wskazuje, że ciała nie mogą poruszać się szybciej od prędkości światła i tak dalej. ID głosi zaś, że pewne procesy fizyczne nie mogą prowadzić do innych specyficznych fizycznych skutków. Na przykład losowe procesy chemiczne nie mogą skonstruować maszynerii życia, a losowe mutacje i dobór nie mogą wytworzyć nowych narządów. (Ostatnio Behe wskazał na jeszcze większe ograniczenia, mianowicie, że poza zasięgiem losowych mutacji i doboru znajduje się zmiana już trzech lub czterech elementów genu. ${ }^{21}$ ) W każdym z tych przypadków formułowane jest falsyfikowalne przewidywanie - aby obalić drugie prawo termodynamiki, wystarczy tylko jeden przykład perpetuum mobile, natomiast podważenie ID wymaga tylko jednego przykładu powstania w laboratorium nowego narządu wskutek działania procesów losowych.

Chcielibyśmy dysponować większą ilością pozytywnych zasad, ale dobra nauka musi przyjmować rzeczywistość taką, jaka jest. Oczekiwanie od zwolenników ID, by formułowali jakieś nowe przewidywania biologiczne, ma tyle samo sensu, co oczekiwanie od fizyków, by opracowali nowe sposoby obalenia drugiego prawa termodynamiki.

Apologetyczne i teologiczne znaczenie ID polega zaś na tym, że teoria ta podważa wielką metanarrację większości ateistów, zgodnie z którą wszystko powstało w wyniku działania niekierowanych procesów losowych, a to, co wygląda na dobrze zaprojektowane i piękne,

\footnotetext{
${ }^{21}$ B EHE, The Edge of Evolution....
} 
zaistniało spontanicznie i bez celu. W pewnym sensie świadectwa, przemawiające za ID, wspierają również teizm, ale nie wskazują jednoznacznie na chrześcijańskiego Boga.

\section{Zakończenie}

W niniejszym artykule argumentowałem, że główny zarzut wobec ID - problem określenia, czym jest brak projektu w świecie zaprojektowanym przez Boga - odpowiada bezpośrednio problemowi wolnej woli, a więc także problemowi istnienia moralnego zła w dobrym świecie.

Choć nie wszyscy filozofowie się z tym zgodzą, zawsze dysponujemy wrodzoną umiejętnością opisywania własnej dziedziny kontroli, w ramach której możemy identyfikować rzeczy, niebędące rezultatem działania Boga, przyjmując jednocześnie, że - na najgłębszym poziomie - Bóg wszystko zrobił dobrze. W obrębie własnej dziedziny kontroli możemy czynić dobro lub zło, a także tworzyć zarówno rzeczy zaprojektowane, jak i niezaprojektowane.

Podążając za Augustynem, zwolennik ID może zatem twierdzić, że wszystko jest w pewnym stopniu dobre, ale niektóre rzeczy mają W sobie więcej dobra niż inne. W mojej dziedzinie obserwacji istnieją rzeczy, na przykład kamienie, które zostały dobrze zaprojektowane na jednym poziomie $\mathrm{w}$ tym sensie, że podlegają dobrze zaprojektowanym prawom przyrody, lecz istnieją też inne, takie jak układy ożywione, które charakteryzują się dodatkowym poziomem projektu, niemożliwym do wywiedzenia wyłącznie z projektu niższego poziomu. Nie należy w związku z tym sądzić, że ID dostrzega Boga tylko w cudach, a w pospolitych zjawiskach - już nie.

Pośród zwolenników ID nie ma zgodności co do tego, jak ten dodatkowy poziom projektu został wprowadzony do świata, i nie należy się spodziewać, że taki jednomyślny scenariusz wkrótce się pojawi. Wprawdzie ID wyklucza niektóre historie, ale formułuje jedynie 
twierdzenia o obserwowanych zjawiskach, nie tworzy całościowych narracji. Zasadniczo zajmuje się jednym problemem: jak zapewnić obiektywną podstawę subiektywnemu - na pierwszy przynajmniej rzut oka - wrażeniu, że pewne rzeczy, w przeciwieństwie do innych, wyglądają na zaprojektowane. 